\title{
Halide-sensitive Fluorescent Probes for Self-assembly of Novel Cationic Fluorosurfactants
}

\author{
Tadahiro Ozawa, Tsuyoshi Asakawa* , Akio Ohta and Shigeyoshi Miyagishi \\ Division of Material Sciences, Graduate School of Natural Science \& Technology \\ (Kanazawa University, Kanazawa 920-1192, JAPAN)
}

Edited by T. Kato, Tokyo Metr. Univ., and accepted November 24, 2004 (received for review September 17, 2004)

\begin{abstract}
Examination was made of the properties of aqueous solutions of cationic fluorosurfactants based on data for the fluorescence quenching of quinoline and acridine derivatives. The fluorosurfactant possessing a chloride counterion gave higher CMC and micellar counterion dissociation compared with those containing bromide. Micellar counterion dissociation was noted to slightly decreased with increase in $\mathrm{NaCl}$ but significantly to do so to less than 30 and $75 \mathrm{mM} \mathrm{NaCl}$ for $\mathrm{C}_{8} \mathrm{~F}_{17} \mathrm{CH}_{2} \mathrm{CH}(\mathrm{OH}) \mathrm{CH}_{2} \mathrm{NH}\left(\mathrm{C}_{2} \mathrm{H}_{5}\right)_{2} \mathrm{Cl}$ and $\mathrm{C}_{8} \mathrm{~F}_{17} \mathrm{CH}_{2} \mathrm{CH}_{2} \mathrm{NC}_{5} \mathrm{H}_{5}$ $\mathrm{Cl}$, respectively. Change in 6-methoxy-N-(3-sulfopropyl)quinolinium (SPQ) fluorescence spectra with hydrogenation served as basis for determining the site of solubilization in micellar solution. Dissolved SPQ in water bulk phase underwent instant reduction with the addition of $\mathrm{NaBH}_{4}$, though SPQ in fluorosurfactant systems showed virtually no reduction owing to solubilization of SPQ in vesicles.
\end{abstract}

Key words: self-assembly of cationic fluorosurfactant, fluorescent probe of quinoline and acridine derivative, fluorescence quenching, the degree of micellar counterion dissociation, hydrogenation of SPQ

\section{1 緒言}

カチオン型のフッ素系界面活性甋に関する研究例は アニオン型に比べて少なく，アニオン型のフッ素系界 面活性剤を合成原料としてカチオン型に誘導したもの が多い $(1-3)$ 。例えば，パーフルオロアルキルカルボ ン酸塩化物とアミン類の反応後, ヨウ化メチルでアン モニウム塩型としたフッ素系界面活性剈が報告されて いる。また, パーフルオロアルキルスルホニルフルオ リドも合成原料として利用されているが，合成された 界面活性剂はクラフト点が高く，水に対する溶解性が 充分とは言えない。一方，代表的なカチオン界面活性 剤の一つであるアルキルピリジニゥム塩は, 八ロゲン 化アルキルとピリジンとの反応で容易に得られる（4）。 この反応を利用して, 我々はこれまでにピリジニウム 塩型のフッ素系界面活性剂を合成し，その水溶液物性 について検討してきた。（5）ヨウ化 $1 \mathrm{H}, 1 \mathrm{H}, 2 \mathrm{H}, 2 \mathrm{H}$-パー
フルオロデシルピリジニウムはクラフト点が $45^{\circ} \mathrm{C}$ と高 いが，イオン交換により塩化物とすると $25^{\circ} \mathrm{C}$ でかな 高濃度まで水に溶解可能となる。そして, 低濃度側で は比較的小さなミセルを形成するのに対し，高濃度側 では棒状や紐状のミセルに成長することを報告してき た（6)。また，ジエチルアミンによるエポキシドの開 環反応で合成したアンモニウム塩型フッ素系界面活性 剂については, 添加塩に伴うべシクル形成を見出した。 すなわち，ミ七ル表面に打ける親水基間の静電的反発 を抑えると，フッ素系界面活性剂は表面曲率の小さな 会合体構造を発現しやすい。これはフルオロカーボン 鎖が嵩高く剛直で高い疎水性を有することなどの特性 に由来する。

本研究では, 蛍光消光法によりミセルの対イオン解 離度を評価し, 添加塩によるミセル会合体構造変化を 蛍光プローブ法により簡便に検出することを目的とす る。蛍光プローブとして，キノリン扎よびアクリジン

\footnotetext{
*Correspondence to: Tsuyoshi AsaKawa, Division of Material Sciences, Graduate School of Natural Science \& Technology, Kanazawa University, Kakumacyou, Kanazawa 920-1192, JAPAN

E-mail: asakawa@t.kanazawa-u.ac.jp
} 
各種誘導体について検討し，ミセル系でバルク水相中 のフリーなハロゲン化物イオン濃度を決定して対イオ ン解離度を評価した。また，八ロゲン化物イオンとし て，臭化物対イオンとするカチオン型フッ素系界面活 性剂を新規合成し，ミセルの溶解状態に対する対イオ ン濃度や種類による影響を検討した。一方，これらの 蛍光プローブは還元剤により水素化されると，その蛍 光強度が減少する特徴を有する（7）。このキノリン環 への水素化に伴う蛍光消光をミセル系に利用すると, 蛍光プローブの溶存位置やベシクル形成の推察が可能 と考えられる。すなわち, ベシクル内水相側に蛍光プ ローブが存在するとき，バルク水相に添加された還元 凨の反応を受けにくいと予想される。蛍光測定のよう な比較的簡便な方法により，ベシクル形成に関する知 見を得ることを目指した。

\section{2 実験}

$2 \cdot 1$ 試 料

6-Methoxy-N-ethylquinolinium iodide(MEQ), 6methoxy-N-(3-sulfopropyl) quinolinium (SPQ), N(ethoxycarbonylmethyl)-6-methoxyquinolinium bromide (MQAE), N-sulfopropylacridinium(SPA) および bis-Nmethylacridinium nitrate(lucigenin) は, Molecular Probe 社の市販品をそのまま使用した。ピリジニウム塩 型界面活性剂 $\mathrm{C}_{8} \mathrm{~F}_{17} \mathrm{CH}_{2} \mathrm{CH}_{2} \mathrm{NC}_{5} \mathrm{H}_{5} \mathrm{I}$ は，対応するヨウ化 アルカンをピリジンとアセトニトリル中で 2 時間還流 して得られた。エーテル洗浄とアセトン再結晶後, イ オン交換樹脂で対応する塩化物 $\mathrm{C}_{8} \mathrm{~F}_{17} \mathrm{CH}_{2} \mathrm{CH}_{2} \mathrm{NC}_{5} \mathrm{H}_{5} \mathrm{Cl}$ （HFDePC） あるいは臭化物 $\mathrm{C}_{8} \mathrm{~F}_{17} \mathrm{CH}_{2} \mathrm{CH}_{2} \mathrm{NC}_{5} \mathrm{H}_{5} \mathrm{Br}$ (HFDePB) とした。一方, ジエチルアンモニウム塩型 界面活性剤の合成は，3-perfluorooctyl-1, 2-epoxypropane を過剩のジエチルアミン存在下，エタノール中で 8 時 間還流して行った。塩酸扎よび臭化水素酸で中和して それぞれ $\mathrm{C}_{8} \mathrm{~F}_{17} \mathrm{CH}_{2} \mathrm{CH}(\mathrm{OH}) \mathrm{CH}_{2} \mathrm{NH}\left(\mathrm{C}_{2} \mathrm{H}_{5}\right)_{2} \mathrm{Cl}\left(\mathrm{FC}_{8} \mathrm{DAC}\right)$ 打よび $\mathrm{C}_{8} \mathrm{~F}_{17} \mathrm{CH}_{2} \mathrm{CH}(\mathrm{OH}) \mathrm{CH}_{2} \mathrm{NH}\left(\mathrm{C}_{2} \mathrm{H}_{5}\right)_{2} \mathrm{Br}\left(\mathrm{FC}_{8} \mathrm{DAB}\right)$ を得た。フッ素系界面活性剤はすべてアセトンで 2 回 再結晶して減圧乾燥後使用した。また，塩化へキサデ シルトリメチルアンモニウム（CTAC）は, 東京化成工 業株式会社の市販品をアセトンとエタノール混合溶媒 で 3 回再結晶を行った。ドデシル硫酸ナトリウム （SDS）は, ナカライテクス株式会社の市販品をエタ ノールで 3 回再結晶を行った。N,N-ジメチルドデシル アミンオキシド（DDAO）は, Flukaより購入した $30 \% \mathrm{DDAO}$ 水溶液を凍結乾燥後, アセトンとジエチル エーテル混合溶媒で 3 回再結晶した。

\section{$2 \cdot 2$ 蛍光測定}

二次蒸留水を用いて, $5 \times 10^{-7} \sim 10^{-6} \mathrm{M}$ 蛍光プローブ 水溶液を調整後, この水溶液中にカチオン界面活性剂 または無機塩等を溶解させた $(8-10)$ 。 $25^{\circ} \mathrm{C}$ の恒温下, 日立 F-2000 型分光蛍光光度計を用いて蛍光スペクトル を記録した。すべての蛍光プローブについて，界面活 性剂の添加による蛍光スペクトルの波長シフトは見ら れず，蛍光波長ピークに打ける蛍光強度を読み取った。

一方, $\mathrm{NaBH}_{4}$ による $\mathrm{SPQ}$ の還元実験は次のように 行った。 $10^{-6} \mathrm{M} \mathrm{SPQ}$ 水溶液 $1 \mathrm{~mL}$ を入れた蛍光測定用石 英セルに $1 \mathrm{M} \mathrm{NaBH}_{4}$ 水溶液をマイクロシリンジで $10 \mu \mathrm{L}$ 添加した。攪拌後すぐ，蛍光スペクトルを記録し，蛍 光強度の経時変化も確認した。なお, $\mathrm{NaBH}_{4}$ は溶存酸 素により失活しやすいので, 水溶液として調整後すぐ 使用した。

$\mathrm{NaBH}_{4}$ 水溶液を $10 \mu \mathrm{L}$ 添加により $\mathrm{SPQ}$ の波長シフト 打よび蛍光強度が一定となり，界面活性剂系に打いて も，すべての SPQ を還元できる実験条件を確認した。

\section{3 結果および考察}

\section{$3 \cdot 1$ 各種蛍光プローブのスペクトルと消光挙動}

キノリンおよびアクリジン誘導体の蛍光プローブと しての特徵を把握するため, 水溶液中における励起お よび蛍光スペクトルを比較した。 $1 \times 10^{-6} \mathrm{M} \mathrm{MEQ}, 1 \times$ $10^{-6} \mathrm{M}$ MQAE, $1 \times 10^{-6} \mathrm{M}$ SPQ, $7 \times 10^{-7} \mathrm{M}$ SPA, $5 \times 10^{-7} \mathrm{M}$ Lucigenin 水溶液のスペクトルをそれぞれ Fig. 1 に示し た。キノリン誘導体である $\mathrm{MEQ}$ と $\mathrm{MQAE}$ および $\mathrm{SPQ}$ の励起ピーク波長は，それぞれ $343 \mathrm{~nm}, 346 \mathrm{~nm}$ 及び $345 \mathrm{~nm}$ であり，いずれも $440 \mathrm{~nm}$ 付近をピークとする ブロードな蛍光が観測された $(8,9)$ 。 $\mathrm{MEQ}$ と MQAE はカチオン性であるのに対し, SPQ は両性イオンであ るがスペクトルや蛍光強度に打ける相違は少ない。一 方，アクリジン誘導体である SPA と Lucigeninの励起 ピーク波長は，それぞれ $357 \mathrm{~nm}$ と $368 \mathrm{~nm}$ であり，蛍 光ピークは $485 \mathrm{~nm}$ 打よび $500 \mathrm{~nm}$ と長波長側に観測さ れた。また, SPA と Lucigenin では, キノリン誘導体 よりも長波長側に吸収帯が存在するため, 短波長側に 吸収帯を有するイオンが存在する場合にも適用可能で ある。例えば，ヨウ化アルキルピリジニウム塩のミセ ル系のように，イオン対生成による $300 \sim 400 \mathrm{~nm}$ 付近 の吸収帯が出現する場合でも, SPA 蛍光消光法により 対イオン解離度が決定できる（10）。Lucigeninについ ても同様な点が指摘できるが，蛍光強度とその消光感 度が大きい点に特徵がある（11）。しかし, 過酸化物に より酸化される際に発光する性質がある点に留意する 必要がある。また， 2 価カチオンの蛍光プローブであ り, 静電的反発によりカチオン性ミセル表面には近づ 


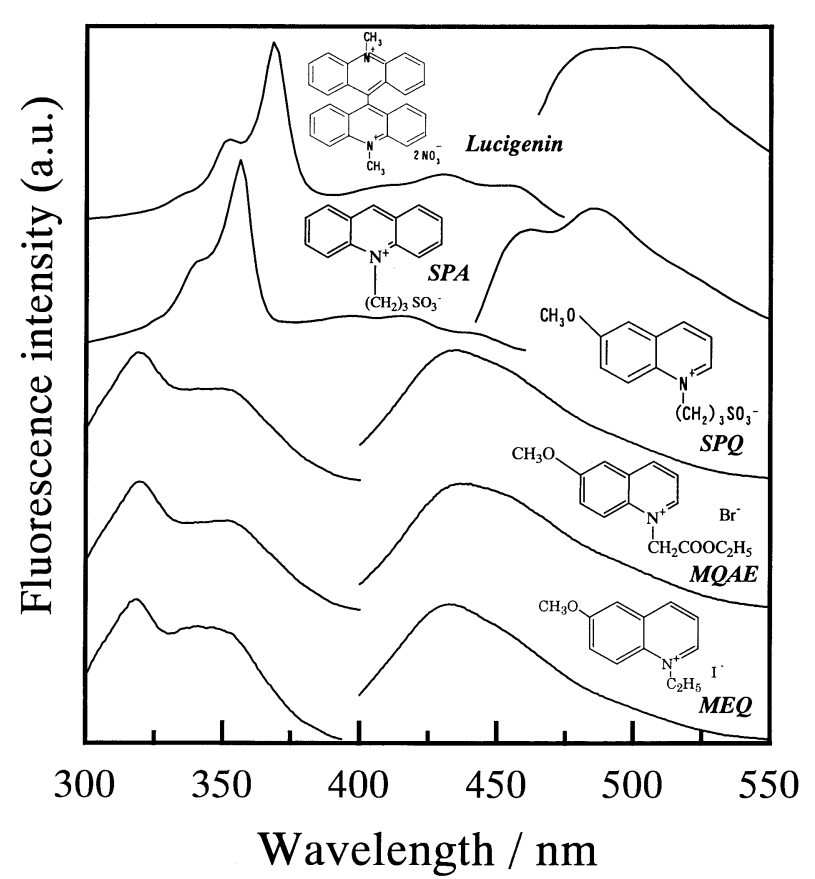

Fig. 1 Excitation and Emission Spectra of Fluorescent Probes in Aqueous Solutions.

きにくいことが予想される。

これらの蛍光はハロゲン化物イオンとの分子衝突に より消光され，蛍光強度比は Stern-Volmer 則に従う (8)。

$$
\mathrm{I}_{0} / \mathrm{I}=1+\mathrm{K}_{\mathrm{SV}}[\mathrm{Q}]=1+\mathrm{k}_{\mathrm{q}} \tau_{0}[\mathrm{Q}]
$$

消光剤濃度 $10 \mathrm{mM}$ までの濃度範囲で測定を行った結 果, すべての蛍光プローブについて蛍光強度比 $\mathrm{I}_{0} / \mathrm{I}$ は 消光剤濃度 $[Q]$ に対して直線関係が成立した。各種無機 塩類による蛍光消光を Stern-Volmer プロットし，直線 の傾きから Stern-Volmer 定数 $\mathrm{K}_{\mathrm{SV}}$ を求め, Table 1 に 示した。無機塩および蛍光プローブの種類によって $\mathrm{K}_{\mathrm{SV}}$ 值に大きな相違が現れた。各種無機塩に対する消光感 度は, $\mathrm{NaI}>\mathrm{NaBr}>\mathrm{NaCl} \gg \mathrm{NaOAc}>\mathrm{NaNO}_{3}, \mathrm{Na}_{2}$ $\mathrm{SO}_{4}$ の順で, Lucigenin 以外の蛍光プローブでは, 硝酸 イオンと硫酸イオンにより消光されないといえる。な 打，対応するカリウム塩やリチウム塩を用いても同様 な結果を確認して打り, カチオンは蛍光消光に関与し ていない。

MQAE，SPQ およびSPAの蛍光寿命 $\tau_{0}$ は，それぞれ 21.6, 25.3, $32.8 \mathrm{~ns}$ と報告されている $(12,13)$ 。MQAE の蛍光寿命が SPAの約 2/3 であるのに, MQAEの $\mathrm{K}_{\mathrm{SV}}$ が SPAより大きいことから, MQAE の消光速度定数 $\mathrm{k}_{\mathrm{q}}$ は SPA より大きく，消光感度が高いといえる。すなわ ち, カチオンの MQAE は, 両性イオンである SPA や
Table 1 Stern-Volmer Constants of Fluorescent Probes.

\begin{tabular}{crrrrc}
\hline & \multicolumn{5}{c}{$\mathrm{K}_{\mathrm{sv}} / \mathrm{M}^{-1}$} \\
\cline { 2 - 6 } Salt & MEQ & MQAE & \multicolumn{1}{c}{ SPQ } & SPA & Lucigenin \\
\hline $\mathrm{NaCl}$ & 169 & 269 & 141 & 16 & 432 \\
$\mathrm{NaBr}$ & 340 & 417 & 233 & 345 & 720 \\
$\mathrm{NaI}$ & 383 & 460 & 252 & 452 & 962 \\
$\mathrm{NaNO}_{3}$ & 0 & 7 & 4 & 2 & 85 \\
$\mathrm{Na}_{2} \mathrm{SO}_{4}$ & 2 & 0 & 1 & 1 & 30 \\
$\mathrm{NaOAc}$ & 2 & 9 & 11 & 2 & 56 \\
$\mathrm{NaSal}$ & - & - & - & 267 & 529 \\
\hline
\end{tabular}

$\mathrm{CH}_{3} \mathrm{COONa}(\mathrm{NaOAc}), \mathrm{HOC}_{6} \mathrm{H}_{4} \mathrm{COONa}(\mathrm{Na} \mathrm{Sal})$

$\mathrm{SPQ} よ り$ 消光感度が高い。これは, MQAEのように負 電荷がないと，アニオンとの分子衝突による消光が起 こりやすく， 2 価カチオンの Lucigenin ではさらに消光 感度が高くなるものと考えられる。

SPA と Lucigenin では, 長波長での励起が可能であ るので, 300 ～ $370 \mathrm{~nm}$ まで吸収帯を有するサリチル酸 ナトリウム（NaSal）にも適用可能であった。CTAC な どのカチオン界面活性剤はサリチル酸ナトリウムの添 加により，紐状ミセルを形成することが報告されてい るが, 対イオン結合度の簡便な決定に利用可能と考え られる（14）。また, SPAのイオン選択性蛍光消光も利 用すると，対イオンの競争結合に関する知見が期待さ れる (15)。

\section{$3 \cdot 2$ フッ素系界面活性剂水溶液系における蛍光消光 挙動}

次に, 界面活性剤水溶液系に各種蛍光プローブを適 用し, 臨界ミセル形成濃度 CMC とミセルの対イオン解 離度 $\alpha$ を評価した。フッ素系界面活性剂濃度に対する SPQ 蛍光消光の Stern-Volmer プロットを Fig. 2 に示し た。無機塩類と同様，臭化物対イオンの方が塩化物対 イオンより良く消光し, 同じ対イオンをもつもの同士 は, Stern-Volmer プロットにおける傾きが一致した。 また, 界面活性剂の濃度増加によりミセル形成すると, 対イオンが一部ミセルに結合するため Stern-Volmer プ ロットに打ける傾きが小さくなった。なお，同様な消 光挙動が Table 1 に示したすべての蛍光プローブについ て観察されている。Stern-Volmer プロットにおける屈 曲点から $\mathrm{CMC}$ を決定し, $\mathrm{CMC}$ 以上と $\mathrm{CMC}$ 以下にお ける傾きの比から $\alpha$ を求め, Table 2 に示した。HFDe$\mathrm{PC}, \mathrm{HFDePB}, \mathrm{FC}_{8} \mathrm{DAC}$, および $\mathrm{FC}_{8} \mathrm{DAB}$ の $\mathrm{CMC}$ は，そ れぞれ $2.71 \pm 0.13,2.03 \pm 0.06,2.32 \pm 0.08,1.83 \pm 0.05$ $\mathrm{mM}$ と評価でき, 蛍光プローブの種類に依存せず, 電 気伝導度法による CMC 值とほぼ一致した（6）。 


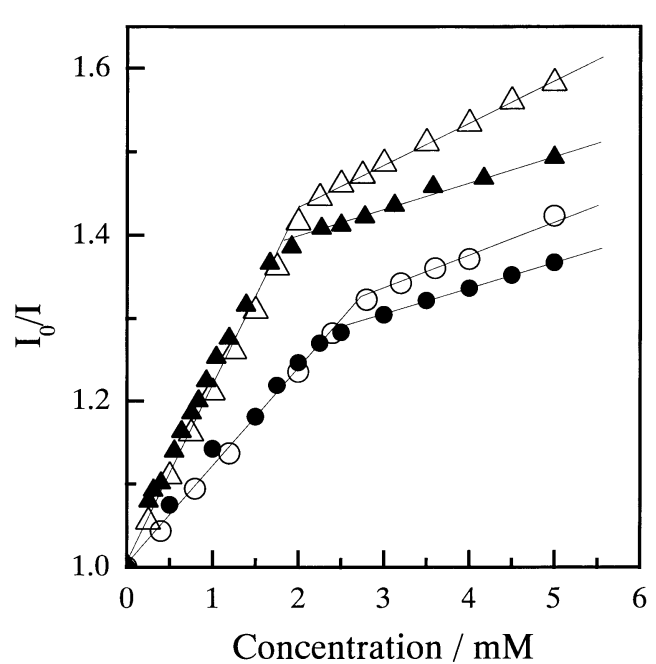

Fig. 2 Stern-Volmer Plots for Quenching of SPQ Fluorescence.

(О) $\mathrm{FC}_{8} \mathrm{DAC},(\boldsymbol{\Delta}) \mathrm{FC}_{8} \mathrm{DAB},(\bigcirc) \mathrm{HFDePC}$, $(\triangle)$ HFDePB.

$\mathrm{FC}_{8} \mathrm{DAC}$ の CMC が HFDePC よりも低いのは, 疎水鎖 長がメチレン基一つ分長いためであり，臭化物の CMC が低いのは, 対イオン解離度が小さいためである。

一方，ミセルの対イオン解離度 $\alpha$ は蛍光プローブの 種類に依存し, カチオンの $\mathrm{MEQ}$ と MQAE に比べて両 性イオン SPQ と SPA により決定した $\alpha$ は大きな值を 示した。これは, 両性イオンプローブのスルホン酸ア ニオンが, カチオン性ミセル表面に近づきに易いため, よりミセル表面近傍に存在するハロゲン化物イオンに よる消光が関与していることが予想される。なお, SPA では，塩化物対イオンを有する界面活性郕の CMC や $\alpha$ を決定することはできなかった。また, MEQ は対イオ ンとしてヨウ化物イオンをもつため, フッ素系界面活 性剂の溶液物性に影響を与える可能性が考えられる点, MQAE は水溶液中の長期保存でエステル基が加水分解 されると, 消光感度に影響がある点, また, Lucigenin はデータの再現性に劣る点に問題があった。そこで, 還元反応を利用した蛍光プローブの溶存位置の推察が
可能でもある SPQ 蛍光プローブを用い，フッ素系界面 活性剂の水溶液物性を検討した。

\section{$3 \cdot 3$ 添加塩系における $S P Q$ 蛍光消光挙動とミセル 成長}

フッ素系界面活性剤が形成するミセルを球状とする と, フルオロカーボン鎖が短く嵪高いため幾何学的考 察から小さな会合数となる。従って, ミセル表面にお ける界面活性剂 1 分子あたりの断面積は大きくなり， 対イオン解離度も大きくなる傾向がある。しかし, 電 離した親水基間の静電的反発を添加塩により抑制する と，ミセル成長することが予想される。フッ素系界面 活性剤が形成するミセルは, 添加塩により棒・紐状あ るいはべシクルへ転移しやすい傾向があることを報告 してきた。HFDePC は小さなミセルを形成するが，添 加塩により紐状ミセルへと転移すること, $\mathrm{FC}_{8} \mathrm{DAC}$ は ベシクルを形成することが cryo-TEM で観察されてい る（6）。そこで, これら会合体の形状変化点を対イオ ン解離度の変化から決定することを検討した。 $\mathrm{FC}_{8} \mathrm{DAC}$ 界面活性剤の $\mathrm{NaCl}$ 添加塩系に打ける $\mathrm{SPQ}$ 监光消光挙 動を，塩化物イオン全濃度に対する Stern-Volmer プ ロットでFig. 3 に示した。添加塩濃度増加とともに良 く消光されるが， CMC 以上に打ける傾きが小さくなっ ている。これは表面曲率の小さな会合体のべシクルに 転移して, 対イオン解離度が小さくなったものと解釈 できる。HFDePC 添加塩系に抢いても SPQ 蛍光消光実 験を行い, Stern-Volmer プロットから得られた CMC と $\alpha$ を Table 3 にまとめた。 $\mathrm{FC}_{8} \mathrm{DAC}$ 系では, $\mathrm{NaCl}$ 添加 塩濃度増加とともに $\alpha$ は 0.28 から 0.21 へと減少し, 30 $\mathrm{mM} \mathrm{NaCl}$ 添加塩濃度以上になると $\alpha$ が 0.04 へと急激 に低下した。一方, HFDePC 系でも, $\mathrm{NaCl}$ 添加塩濃度 増加とともに $\alpha$ は 0.34 から 0.25 へ減少し, $75 \mathrm{mM}$ $\mathrm{NaCl}$ 添加塩濃度以上になると $\alpha$ が 0.12 へ低下した。 cryo-TEM による観察結果と考えあわせると， $30 \mathrm{mM}$ $\mathrm{NaCl}$ で $\mathrm{FC}_{8} \mathrm{DAC}$ ミセル゙ベシクルに, $75 \mathrm{mM} \mathrm{NaCl}$ で HFDePC ミセルが紐状に転移したことに対応している。

Table 2 CMC and the Degree of Micellar Counterion Dissociation for Cationic Fluorosurfactants.

\begin{tabular}{|c|c|c|c|c|c|c|c|c|c|c|}
\hline & \multicolumn{2}{|c|}{ MEQ } & \multicolumn{2}{|c|}{ MQAE } & \multicolumn{2}{|c|}{ SPQ } & \multicolumn{2}{|c|}{ SPA } & \multicolumn{2}{|c|}{ Lucigenin } \\
\hline & $\mathrm{CMC} / \mathrm{mM}$ & $\alpha$ & $\mathrm{CMC} / \mathrm{mM}$ & $\alpha$ & $\mathrm{CMC} / \mathrm{mM}$ & $\alpha$ & $\mathrm{CMC} / \mathrm{mM}$ & $\alpha$ & $\mathrm{CMC} / \mathrm{mM}$ & $\alpha$ \\
\hline HFDePC & 2.80 & 0.26 & 2.53 & 0.33 & 2.70 & 0.34 & - & - & 2.80 & 0.34 \\
\hline HFDePB & 2.12 & 0.13 & 2.01 & 0.23 & 2.06 & 0.23 & 1.98 & 0.24 & 2.00 & 0.16 \\
\hline $\mathrm{FC}_{8} \mathrm{DAC}$ & 2.34 & 0.17 & 2.38 & 0.22 & 2.20 & 0.28 & - & - & 2.35 & 0.10 \\
\hline $\mathrm{FC}_{8} \mathrm{DAB}$ & 1.80 & 0.15 & 1.77 & 0.18 & 1.85 & 0.18 & 1.83 & 0.19 & 1.89 & 0.09 \\
\hline
\end{tabular}




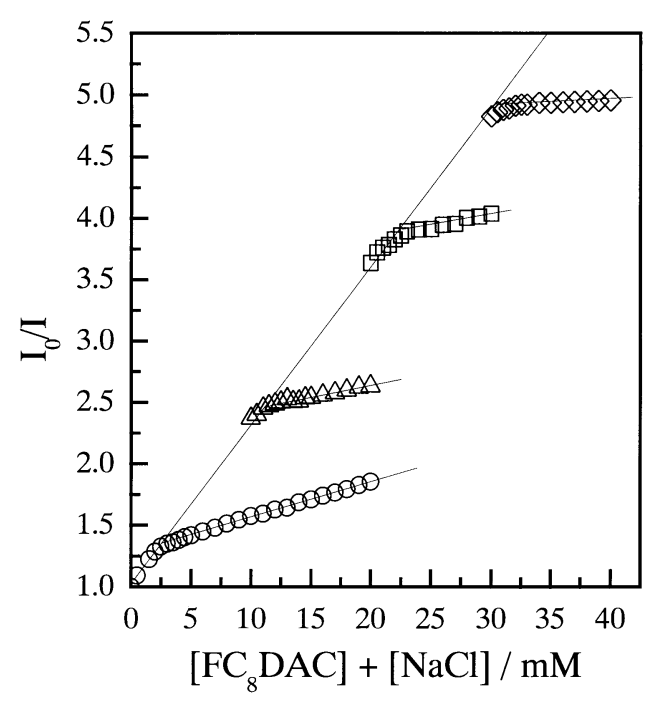

Fig. 3 Stern-Volmer Plots for Quenching of SPQ Fluorescence by Chloride Ions.

(○) $\mathrm{FC}_{8} \mathrm{DAC},(\triangle) \mathrm{FC}_{8} \mathrm{DAC}+10 \mathrm{mM} \mathrm{NaCl}$, $(\square) \mathrm{FC}_{8} \mathrm{DAC}+20 \mathrm{mM} \mathrm{NaCl},(\diamond) \mathrm{FC}_{8} \mathrm{DAC}+$ $30 \mathrm{mM} \mathrm{NaCl}$.

\section{$3 \cdot 4 \mathrm{SPQ}$ の水素化による蛍光消光挙動}

キノリン誘導体は還元凰 $\mathrm{NaBH}_{4}$ により水素化され， 蛍光スペクトルの長波長シフトとその蛍光強度の急激
Table 3 Effect of $\mathrm{NaCl}$ Addition on the Degree of Micellar Counterion Dissociation.

\begin{tabular}{ccc}
\hline \multirow{2}{*}{$\mathrm{NaCl} / \mathrm{mM}$} & \multicolumn{2}{c}{$\alpha$} \\
\cline { 2 - 3 } & $\mathrm{FC}_{8} \mathrm{DAC}$ & HFDePC \\
\hline 0 & 0.28 & 0.34 \\
10 & 0.22 & 0.31 \\
20 & 0.21 & 0.26 \\
30 & 0.04 & 0.26 \\
50 & - & 0.25 \\
75 & - & 0.12 \\
100 & - & 0.09 \\
\hline
\end{tabular}

な減少が報告されている（7）。本研究では，この水素 化還元反応をミセル系に適用して, SPQ 蛍光プローブ の溶存位置やべシクルの存在を推定する方法を確立す る。すなわち，バルク水相に $\mathrm{NaBH}_{4}$ を添加して，水素 化還元反応を蛍光測定により追跡し，ベシクル内水相 側に溶存する $\mathrm{SPQ}$ 蛍光プローブの存在を推定する。な 打，この水素化還元反応をピリジニウム塩界面活性剂 系で行うと, ピリジン環への水素化が起こり SPQ プ ローブの溶存位置の推定に利用できなかった。

$10^{-6} \mathrm{M} \mathrm{SPQ}$ 水溶液中, $1 \mathrm{mM} \mathrm{NaBH}_{4}$ による $\mathrm{SPQ}$ の水 素化還元に伴う蛍光スペクトル変化を Fig. 4 （a）に示

(b)

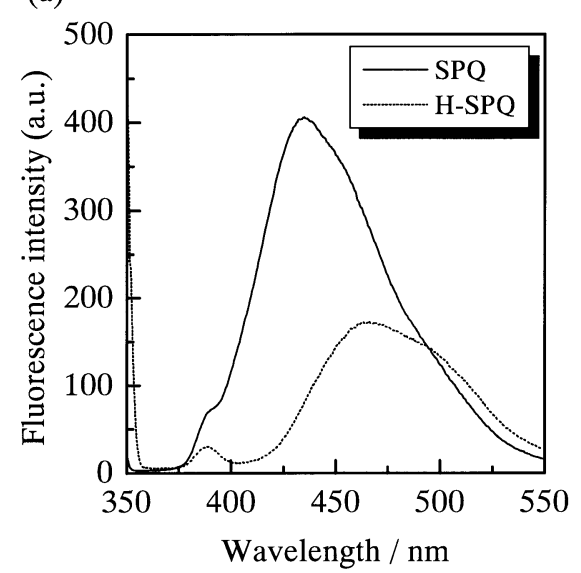

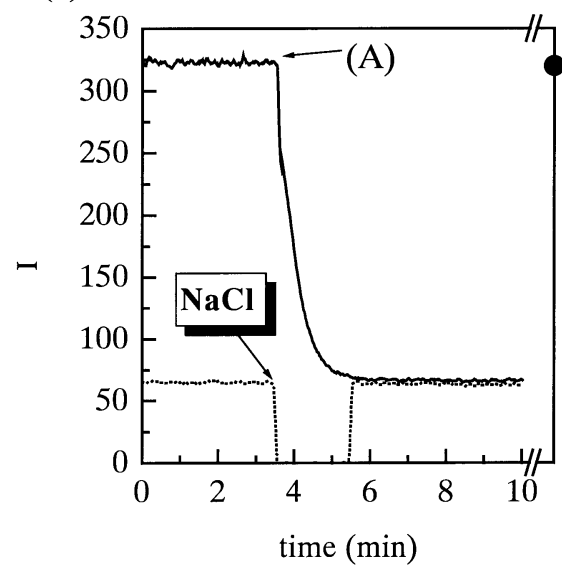

Fig. 4 (a) Effect of $\mathrm{NaBH}_{4}$ Addition on SPQ Fluorescence Spectra.

The dotted lines indicate the fluorescence spectra after the addition of $\mathrm{NaBH}_{4}$.

(b) Time Course of Fluorescence Intensity in Aqueous Solutions.

The solid and dotted lines correspond to the data of SPQ and H-SPQ, respectively. The decrease in intensity was produced by the addition of $\mathrm{NaBH}_{4}$ (arrow A).

The abrupt decrease in intensity was produced by the cut-out of excitation light in order to dissolve $\mathrm{NaCl}$. 
した。 $\mathrm{NaBH}_{4}$ 添加により蛍光極大波長は $465 \mathrm{~nm}$ にシ フトし，蛍光強度は半分以下に減少した。また， 440 $\mathrm{nm}$ に打ける蛍光強度の経時変化を Fig. 4 （b）に示し た。 $\mathrm{NaBH}_{4}$ 添加（罒中の A 点）に伴い蛍光強度は急激 に減少し, 添加 2 分後にほぼ一定となった。SPQ 濃度 に対して過㮃の $\mathrm{NaBH}_{4}$ を添加しているため, 還元反応 は極めて速く起こるものと考えられる。また，この溶 液を数日間放置すると, 溶存酸素による酸化反応によ り $\mathrm{NaBH}_{4}$ 添加前の $\mathrm{SPQ}$ 蛍光スペクトルへと戻る傾向 があった。また，過酸化水素水を添加することによっ ても, $\mathrm{NaBH}_{4}$ 添加前の $\mathrm{SPQ}$ 蛍光スペクトルに戻ること を確認した。なお，SPQ は両性イオンのため，キノリ ン環の還元による正電荷の消失によっても沈殿するこ とはなかった。一方, あらかじめ水中ですべて還元さ

(a)

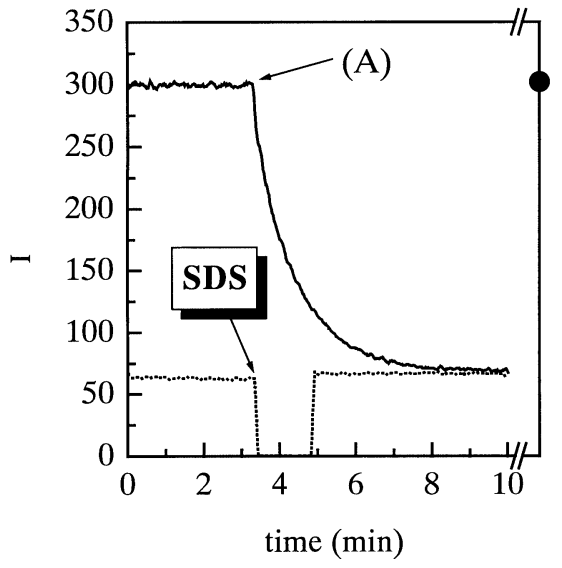

(c)

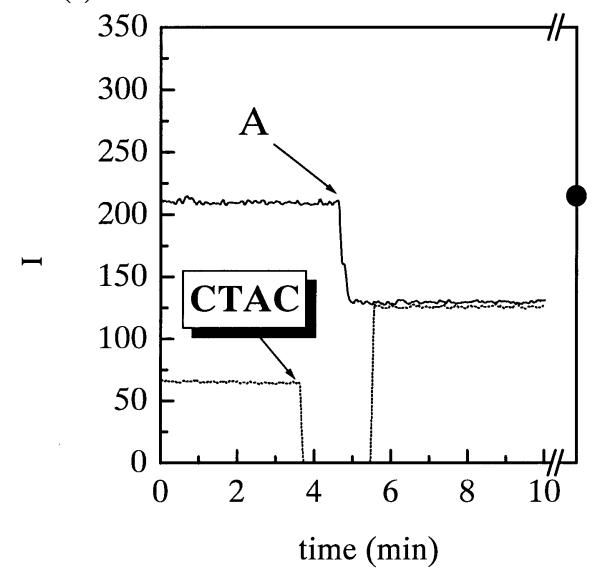

せた SPQ（H-SPQ）水溶液を用いた実験も別に行い， Fig. 4 (b) に比較として示してある。なお， 4 5 分 前後で䖢光強度がゼロを示しているのは, $\mathrm{NaCl}$ を溶解 させる際の励起光の遮断による。蛍光強度が一定であ ることを確認後, $\mathrm{H}-\mathrm{SPQ}$ 水溶液に $\mathrm{NaCl}$ を添加してい るが, H-SPQ は塩化物イオンによる消光が起こらない ことがわかる。

各種界面活性剂ミセル系で SPQ の水素化還元反応を 行い, 蛍光強度の経時変化を Fig. 5 に示した。また, あらかじめ水中ですべて還元させた $\mathrm{SPQ}$ （H-SPQ）水 溶液に, 界面活性凨を溶解させたときの蛍光強度変化 を比較として示した。ミセル系でも還元させた SPQ 水 溶液を保存しておくと, 1 週間後には $\mathrm{NaBH}_{4}$ 添加前の $\mathrm{SPQ}$ の蛍光スペクトルに戻ることを確認した。
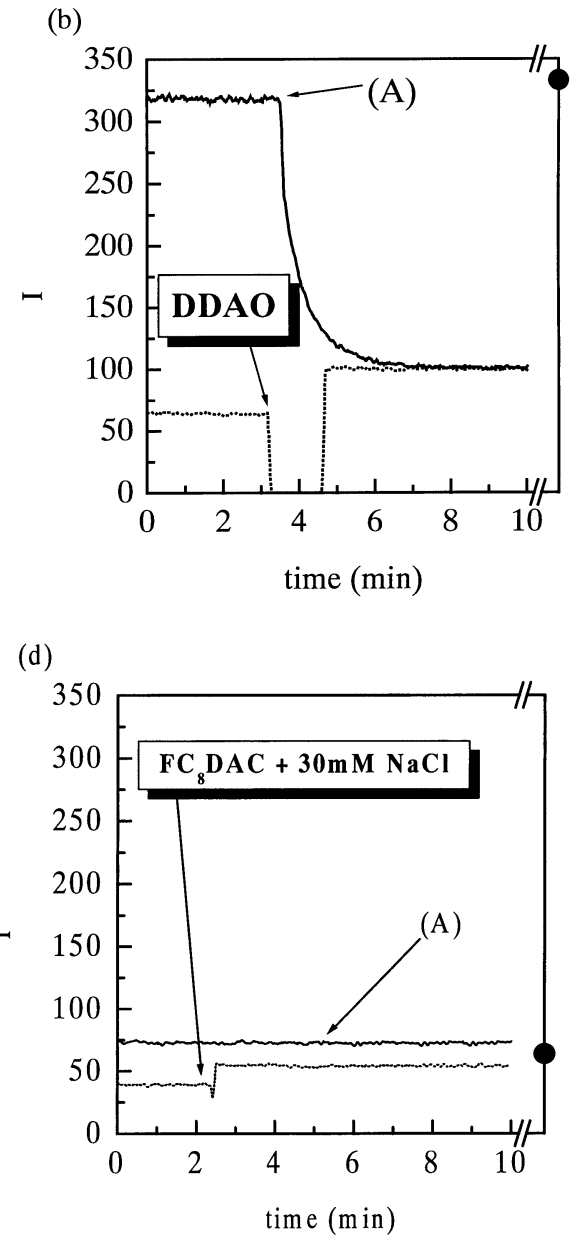

Fig. 5 Time Course of Fluorescence Intensity in Micellar Systems.

The solid and dotted lines correspond to the data of SPQ and H-SPQ, respectively. The decrease in intensity was produced by the addition of $\mathrm{NaBH}_{4}$ (arrow A).
(a) $20 \mathrm{mM}$ SDS (b) $10 \mathrm{mM}$ DDAO (c) $10 \mathrm{mM}$ CTAC
(d) $10 \mathrm{mM} \mathrm{FC}_{8} \mathrm{DAC}+30 \mathrm{mM} \mathrm{NaCl}$

(O) Intensities after 7 days 


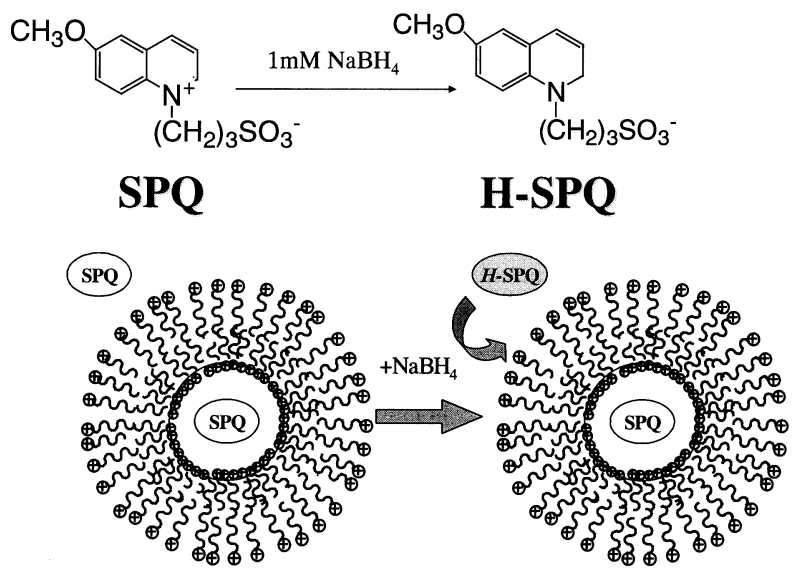

Scheme 1

$\mathrm{NaBH}_{4}$ 添加前の $\mathrm{SPQ}$ 蛍光強度は, すべての系でほぼ 一定の安定な值を示しているが, SDS, DDAO および CTAC 系では, $\mathrm{NaBH}_{4}$ 添加に伴い蛍光強度が減少して いる。SDS 系では, 一定の蛍光強度を示すのに 4 分程 度要した。これは, アニオン性ミセルの静電的反発が $\mathrm{SPQ}$ の還元反応速度を抑制しているものと予想される。 また，DDAO 非イオンミセル系では，水系と似通った 蛍光強度の減少を示し, 還元反応速度に対するミセル の影響はないと言える。一方, CTAC 系では, 最も急 激な蛍光強度の減少が観測された。なお, $\mathrm{NaBH}_{4}$ 添加 前の SPQ 蛍光強度が小さいのは, 塩化物イオンにより $\mathrm{SPQ}$ の蛍光消光が起こっているためである。また， $\mathrm{FC}_{8} \mathrm{DAC}$ 添加塩系では, $\mathrm{NaBH}_{4}$ 添加によっても蛍光強 度はほぼ一定值を示した。これは, SPQ が $\mathrm{NaBH}_{4}$ によ る還元を受けにくい溶存位置にあると考えられる。 $\mathrm{FC}_{8} \mathrm{DAC}$ がベシクルを形成するという cryo-TEM 観察結 果と考え合わせると, ベシクル内水相側に SPQ が溶存 していると予想される (Scheme 1)。

一方, H-SPQ 水溶液に界面活性剂を溶解させたとき の蛍光強度は, SDS, DDAO および CTAC 系では, 各 ミセル系で SPQ が還元されたときの蛍光強度に一致す るのに対し， $\mathrm{FC}_{8} \mathrm{DAC}$ 系では一致しなかった。すなわ ち, SDS, DDAO および CTAC 系ではすべての SPQ が 還元されるが, $\mathrm{FC}_{8} \mathrm{DAC}$ 系においては $\mathrm{SPQ}$ が還元され ていないことが確認できる。また，還元された H-SPQ はミセルへ可溶化されると蛍光強度が変化することが 分かる。H-SPQ はアニオン性のためカチオン性ミセル に良く可溶化され，スペクトル変化により CTAC 系に 打ける H-SPQ の蛍光強度が水系のときより大きくなる と考えられる。

\section{4 結 論}

ハロゲン化物イオン選択性蛍光プローブの蛍光消光 挙動を利用すると, カチオン界面活性剤の CMC と対イ オン解離度が簡便に決定でき, フッ素系界面活性剂ミ セルは添加塩により対イオン結合度の大きな会合体に 転移することが明らかとなった。また, SPQの水素化 還元による蛍光消光の特性から, ベシクル内水相側に 溶存する SPQ の存在が推定できる。このような蛍光消 光挙動から, 比較的少量のサンプルでも他の実験手法 では得られない定量的知見が得られることが分かった。 ベシクル内水相中で濃度消光したカルボキシフルオレ セインの漏出に伴う蛍光強度増加を観察する実験が良 く行われているが, SPQの還元に伴う蛍光スペクトル 変化を利用すれば，ゲルろ過などでべシクル外水相中 の蛍光プローブを除去しなくてもべシクルの存在を示 すことが可能である。

\section{References}

1. C. KIMURA, K. MURAI, K. KASHIWAYA, H. TAKAHASHI and T. NISHIYAMA, Preparation and Surface Active Properties of Perfluorooctanesulfonamide Derivatives, Yukagaku, Vol. 31, 448-451 (1982).

2. C. KIMURA, K. MURAI, K. KASHIWAYA, T. KANNO and T. NISHIYAMA, Preparation and Surface Active Properties of Perfluorooctanamidopropylenedimethylamine Derivatives, Yukagaku, Vol. 31, 462-466 (1982).

3. E. KISSA, Fluorinated Surfactants, Marcel Dekker Inc., New York, (1994).

4. K. FUJIO and S. IKEDA, Size of Spherical Micelles of Dodecylpyridinium Bromide in Aqueous $\mathrm{NaBr}$ Solutions, Langmuir, Vol. 7, 2899-2903 (1991).

5. T. ASAKAWA, H. HISAMATSU and S. MIYAGISHI, Micellar Pseudophase Separation Regions of $1 \mathrm{H}, 1 \mathrm{H}, 2 \mathrm{H}, 2 \mathrm{H}$-Perfluoroalkylpyridinium Chloride and Hydrocarbon Surfactants by Group Contribution Method, Langmuir, Vol. 11, 478-482 (1995).

6. K. WANG, G. KARlsSon, M. ALMGren and T. ASAKAWA, Aggregation Behavior of Cationic Fluorosurfactants in Water and Salt Solutions. A Cryo-TEM Survey, J. Phys. Chem. B, Vol. 103, 9237-9246 (1999).

7. J. BIWERSI and A.V. VERKMAN, Cell-Permeable Fluorescent Indicator for Cytosolic Chloride, Biochemistry, Vol. 30, 78797883 (1991).

8. T. ASAKAWA, H. KITANO, A. OHTA and S. MIYAGISHI, Convenient Estimation for Counterion Dissociation of Cationic Micelles Using Chloride-Sensitive Fluorescence Probe, J. Colloid Interface Sci., Vol. 242, 284-287 (2001).

9. S. ISHINO, T. ASAKAWA, A. OHTA and S. MIYAGISHI, Fluorescence Quenching of Quinoline Derivatives in a Micelle System, J. Oleo Sci., Vol. 52, 535-540 (2003). 


\section{T. Ozawa, T. Asakawa, A. Ohta et al.}

10. T. ASAKAWA, K. IRIYAMA, A. OHTA and S. MIYAGISHI, Micellar Counterion Binding for Alkylpyridinium Iodides Probed by N-Sulfopropylacridinium Fluorescence Quenching, J. Oleo Sci., Vol. 53, 445-451 (2004).

11. K.D. LEGG and D.M. HERCULES, Quenching of Lucigenin Fluorescence, J. Phys. Chem., Vol. 74, $2114-2119$ (1970).

12. A.S. VERKMAN, M.C. SELLER, A.C. CHAO, T. LEUNG and R. KETCHAM, Synthesis and Characterization of Improved Chloride-Sensitive Fluorescent Indicators for Biological Applications, Anal. Biochem., Vol. 178, 355-361 (1989).

13. R.B. THOMPSON and E. GRATTON, Phase Fluorometric
Method for Determination of Standard Lifetimes, Anal Chem., Vol. 60, 670-674 (1988).

14. V.K. MAGID, Z. HAN, G.G. WARR, M.A. Cassidy, P.D. BUTLER and W.A. HAMILTON, Effect of Counterion Competition on Micellar growth Horizon for Cetyltrimethylammonium Micellar Surfaces: Electrostatics and Specific Binding, J. Phys. Chem. B, Vol. 101, 7919-7927 (1997).

15. L.J. ASWAL, Effect of Hydrophobicity of Aromatic Counterions on the Structure of Ionic Micelles, J. Phys. Chem. B, Vol. 107, 13323-13328 (2003). 